\title{
discussion papers
}

FS IV $99-18$

Costly Information Acquisition and

Delegation to a "Liberal" Central Banker

Johan Lagerlöf

October 1999

ISSN Nr. 0722 - 6748

Forschungsschwerpunkt Marktprozeß und Unternehmensentwicklung

Research Area

Market Processes and Corporate Development 
Zitierweise/Citation:

Johan Lagerlöf, Costly Information Acquisition and Delegation to a "Liberal" Central Banker, Discussion Paper FS IV 99 - 18, Wissenschaftszentrum Berlin, 1999.

Wissenschaftszentrum Berlin für Sozialforschung gGmbH, Reichpietschufer 50, 10785 Berlin, Tel. (030) 25491 - 0 


\section{ABSTRACT}

\section{Costly Information Acquisition and Delegation to a "Liberal" Central Banker}

by Johan Lagerlöf*

This paper studies an extension of Rogoff (1985) where the central banker can choose how much effort to exert and thereby learn about a supply shock. With this assumption, it is not necessarily optimal for society to delegate to a "conservative" banker. This may explain why such delegation often is a politically controversial issue.

\section{ZUSAMMENFASSUNG}

\section{Kostenverursachende Informationsbeschaffung und Delegation an einen „liberalen“ Zentralbankier}

Der Aufsatz befaßt sich mit einer Erweiterung der Arbeit von Rogoff (1985), in welcher ein Zentralbankier darüber entscheidet, wieviel Anstrengung er unternehmen möchte, um Informationen über einen Angebotsschock zu erhalten. Ausgehend von dieser Annahme ist es nicht notwendigerweise optimal für die Gesellschaft an einen „konservativen“ Zentralbankier zu delegieren. Dies erklärt unter Umständen, warum Delegation oft ein politisch kontroverses Thema ist.

I have benefited from helpful discussions with and comments from Jonas Björnerstedt, Yeongjae Kang, Nippe Lagerlöf, Susanne Lohmann, César Martinelli, Björn Persson, David Sundén, Karl Wärneryd, and Jörgen Weibull. Financial support from Jan Wallander and Tom Hedelius' Foundation is gratefully acknowledged. A major revision of this paper was carried out as part of a CEPR research network on The Evolution of Market Structure in Network Industries, funded by the European Commission under the Training and Mobility of Researchers Programme (contract No. ERBFMRXCT980203). 


\section{Introduction}

Since the work of Kydland and Prescott (1977) and Barro and Gordon (1983), it is well known that monetary policy may suffer from a credibility problem. Rogoff (1985) suggests that this problem and the inflation bias that it gives rise to can be reduced if society delegates the task of conducting monetary policy to an independent and "weight conservative" central banker. Although Rogoff's solution to the credibility problem is only second best, it does give a better outcome than having a central banker with the same preferences as the rest of society. Thus, if the theory is right, one should expect countries that do not already have an independent central bank to take the opportunity to reform their monetary institutions. Indeed, in many OECD countries one has the last few years been able to observe a move towards a greater central bank independence. However, as Muscatelli (1999, p. 241) notes, "[i]n countries where there has been little or no tradition of [central bank] independence (e.g. the United Kingdom, France) this issue has been hotly debated". Apparently, delegation to an independent and conservative central banker is not perceived by everybody as something unambiguously good.

An alternative solution to the credibility problem is suggested by Walsh (1995). ${ }^{1}$ He points out that the inflation bias can be completely eliminated by designing a simple performance contract for the central banker. This gives an outcome that is first best. Moreover, now there is no role for a central banker with some particular private preferences. However, Herrendorf and Lockwood (1997) consider a setting where wage setters have some private information, for instance about a supply shock, prior to setting the nominal wage. They show that if the central banker's contract cannot be made conditional on this information, then the optimal choice of objectives for an independent central banker will include weight conservatism. ${ }^{2}$ This result indicates that the private preferences of the banker do make a difference, and that Rogoff's delegation story may indeed be useful when thinking about the optimal choice of central bank objectives.

Within his framework of an optimal and complete contract, ${ }^{3}$ Walsh (1995) also considers the interesting and realistic possibility that the appointed central banker, once in office, gets to see a noisy signal about a supply shock, and by exerting effort she can improve upon the quality of this signal. As Walsh suggests (p. 161), a signal with higher quality may for instance be due to a better forecast, and a better forecast may be more costly to produce because it requires more data-collection, more intensive monitoring of financial-market developments, or

\footnotetext{
${ }^{1}$ See also Persson and Tabellini (1993).

${ }^{2}$ Muscatelli (1999) analyzes a model with uncertainty about the central banker's preferences and shows that this may also make weight-conservatism preferable.

${ }^{3}$ Strictly speaking, the optimal contract that Walsh studies is not complete. The important point, however, is that the Walsh contract is sufficiently complete to achieve first best whereas the Herrendorf and Lockwood contract is not.
} 
greater staff resources devoted to forecasting. Walsh shows that, also with this extension, the first-best outcome can be sustained using a simple performance contract. Moreover, there is still no role for a central banker with other preferences than the rest of society.

In this paper I follow the example of Walsh (1995) and study the incentives for a central banker to make an effort (in particular, to acquire costly information), although in a setting where society cannot write a complete contract. For simplicity I take the approach of Rogoff and assume that society's only instrument is to choose to whom it wants to delegate. I thus consider a standard version of Rogoff (1985), extended in a straightforward way to allow for endogenous information acquisition on the part of the central banker. By using this modeling approach I can in a simple way make the following simple point: Provided the banker chooses how much effort to exert once she is in office, this will alter society's incentives when deciding to whom it should delegate. In particular, the banker's opportunity to make an effort adds an incentive for society to delegate to someone who cares more about employment and less about inflation, relative to what would be the case in Rogoff's model. The reason for this is that a banker who cares more about employment will make a greater effort finding information about the supply shock. If the credibility problem in Rogoff's model is not too severe, this "information acquisition effect" will offset the incentives to delegate to someone more conservative or even make it optimal to delegate to a banker who is more "liberal." This result may serve as one possible explanation why many people do not want the conduct of monetary policy to be delegated to someone caring less about employment. ${ }^{4}$

\section{Model}

The following simple version of Rogoff's (1985) model closely follows the setting in Persson and Tabellini (1990, 1997), although I add an opportunity for the appointed central banker to make an effort and thereby improve upon the quality of a signal that she gets to see.

Society's preferences are described by the following quadratic loss function:

$$
\widehat{L}(\pi, x)=\pi^{2}+\lambda(x-\bar{x})^{2},
$$

where $\pi$ is the rate of inflation, $x$ is the level of employment, $\bar{x} \geq 0$ is the most preferred employment level, and $\lambda>0$ is a weight. The relationship between employment and inflation is given by the following expectations-augmented Phillips

\footnotetext{
${ }^{4}$ Muscatelli (1999) also offers an explanation of this phenomenon. His suggested explanation relies on the assumption that the preferences of the prospective central bankers are not perfectly known, which makes delegation more costly.
} 
curve:

$$
x=\beta\left(\pi-\pi^{e}\right)-\varepsilon,
$$

where $\beta>0$ is a fixed parameter, $\pi^{e}$ is the expected inflation rate, and $\varepsilon$ is a supply shock. Initially the magnitude of the supply shock $\varepsilon$ is unknown to everybody; the distribution of $\varepsilon$ is known though and in particular that $E(\varepsilon)=0$. It will be convenient to let $L(\pi)$ denote society's loss function when the expectationsaugmented Phillips curve has been substituted for $x$ in $\widehat{L}(\pi, x)$ :

$$
L(\pi)=\pi^{2}+\lambda\left[\beta\left(\pi-\pi^{e}\right)-\varepsilon-\bar{x}\right]^{2} .
$$

The timing of events is as follows. (i) Society delegates the task of conducting monetary policy to an independent central banker. Prospective central bankers have loss functions that take the form of (2.3) but differ in their personal values of $\lambda$. (ii) The private market observes the preferences of the appointed banker and then forms its expectations about the inflation rate, $\pi^{e}$. (iii) The banker takes office. Once in office, she first decides on an effort level $e$; then she observes a signal, $s$, that is correlated with the supply shock $\varepsilon$. (iv) The central banker decides on the inflation rate $\pi$. (v) The supply shock is realized.

It is assumed that $e \equiv \rho^{2}$, where $\rho$ is the correlation coefficient between $s$ and $\varepsilon$; hence $e \in[0,1]$. Thus, by making a greater effort, the central banker can improve upon the quality of the signal. However, making an effort is costly for the central banker; the disutility that she incurs from exerting effort level $e$ equals $C(e)$, where $C^{\prime}>0$ and $C^{\prime \prime}>0$ with $C^{\prime}(0)=0$. Throughout the paper the only exception being Example 1 - it is also assumed that the cost function satisfies the Inada condition $\lim _{e \rightarrow 1} C^{\prime}(e)=\infty$.

Let $F$ be the joint cumulative distribution function of $\varepsilon$ and $s$, with density $f$. The following notation will be used: $\mu_{s}=E(s), \sigma_{s}^{2}=\operatorname{Var}(s), \sigma^{2}=\operatorname{Var}(\varepsilon)$, and $\rho=\operatorname{Cov}(\varepsilon, s) /\left(\sigma \sigma_{s}\right)$. (Recall that the expected value of $\varepsilon$ equals zero, $E(\varepsilon)=0$.) Thus, as already mentioned, $\rho$ is the correlation coefficient between $s$ and $\varepsilon$.

It is assumed that, after having observed the signal $s$, the central banker updates her beliefs about the shock $\varepsilon$ using Bayes' rule. Thus, her beliefs are described by the conditional density function $f(\varepsilon \mid s)$ defined by $f(\varepsilon \mid s)=f(\varepsilon, s) / f(s)$, where $f(s)=\int f(\varepsilon, s) d \varepsilon$ is the marginal density of $s$. The conditional expectation function is defined by $E(\varepsilon \mid s)=\int \varepsilon f(\varepsilon \mid s) d \varepsilon$. It is assumed that $F$ is such that $\varepsilon$ has linear regression with regard to $s$, i.e., that $E(\varepsilon \mid s)$ is a linear (affine) function of $s$. It is well known that if $\varepsilon$ has linear regression with regard to $s$ (and if $E(\varepsilon)=0)$, then

$$
E(\varepsilon \mid s)=\rho \frac{\sigma}{\sigma_{s}}\left(s-\mu_{s}\right) .
$$

This relationship will be used later on in the analysis. 
It is also assumed that the private market forms its expectations about the inflation level rationally. That is, the expected rate of inflation, $\pi^{e}$, is given by

$$
\pi^{e}=E_{\varepsilon, s}(\pi) .
$$

Hence, $\pi^{e}$ equals the expected value of the actual rate of inflation at the stage where only the prior distribution of $\varepsilon$ and $s$ is known.

\section{Analysis}

Let us denote the central banker's $\lambda$-parameter by $\lambda_{B}$ and her (reduced form) loss function by $L_{B}$. That is, $L_{B}$ is given by $(2.3)$ but with $\lambda_{B} \in[0, \infty)$ substituted for $\lambda$. At the last stage, the central banker will implement the inflation rate $\pi$ that minimizes her expected loss conditional on her having observed the signal $s$, taking into account that a change in $\pi$ affects the employment level $x$ according to the expectation augmented Phillips curve. That is, the central banker solves the following problem:

$$
\min _{\pi} \int L_{B}(\pi) f(\varepsilon \mid s) d \varepsilon
$$

Taking the first-order condition of this problem and then solving for $\pi$ yield

$$
\pi_{B}^{*}=\frac{\lambda_{B} \beta\left[\beta \pi^{e}+E(\varepsilon \mid s)+\bar{x}\right]}{1+\lambda_{B} \beta^{2}} .
$$

The expected rate of inflation is obtained by taking expectations with respect to $s$ of both sides of equation (3.2), using the fact that $E_{s}(E(\varepsilon \mid s))=E(\varepsilon)=0$, and then solving for $\pi^{e}$. Doing this yields $\pi^{e}=\lambda_{B} \beta \bar{x}$. Substituting this expression for $\pi^{e}$ into equation (3.2) in turn yields

$$
\pi_{B}^{*}=\lambda_{B} \beta \bar{x}+\frac{\lambda_{B} \beta E(\varepsilon \mid s)}{1+\lambda_{B} \beta^{2}} .
$$

That is, on average, the equilibrium rate of inflation equals $\lambda_{B} \beta \bar{x}$, which typically is greater than zero - the ideal level according to equation (2.1). This "inflation bias" arises because an average inflation rate of zero is not credible (or time consistent). The reason for this is that at $\pi=0$, the marginal benefit of surprise inflation exceeds the marginal cost of inflation. For the marginal cost of inflation just to balance the marginal gain from an increase in employment, it must be that the average inflation equals $\lambda_{B} \beta \bar{x}$. Thus, the zero rate of inflation would indeed be time consistent if the employment goal, $\bar{x}$, were equal to the "natural" rate of employment, normalized to zero in equation (2.2).

Let $E L_{B}$ denote the central banker's expected loss at the stage where she is to choose the effort level $e$. At this point in time, she only knows the prior 
distribution of $s$ and $\varepsilon$. Of course, however, she anticipates that later, when knowing $s$, she will choose the level of inflation according to (3.3). Hence, we get

$$
\begin{aligned}
E L_{B} & =\iint L_{B}\left(\pi_{B}^{*}\right) f(\varepsilon, s) d \varepsilon d s+C(e) \\
& =\left(\lambda_{B} \beta \bar{x}\right)^{2}-\frac{\lambda_{B}^{2} \beta^{2} \sigma^{2} e}{1+\lambda_{B} \beta^{2}}+\lambda_{B}\left(\bar{x}^{2}+\sigma^{2}\right)+C(e),
\end{aligned}
$$

where the last term is the postulated cost of exerting effort. The expression after the second equality sign in (3.4) was obtained by using equations (2.3), (2.4), (3.3), the identity $e=\rho^{2}$, and carrying out some algebra.

The problem of minimizing $E L_{B}$ with respect to $e$ subject to the constraint $e \in[0,1]$ has the solution $e^{*}$ defined by:

$$
\frac{\lambda_{B}^{2} \beta^{2} \sigma^{2}}{1+\lambda_{B} \beta^{2}}=C^{\prime}\left(e^{*}\right)
$$

Note for future use that

$$
\frac{\partial e^{*}}{\partial \lambda_{B}}=\frac{\beta^{2} \sigma^{2} \lambda_{B}\left(2+\lambda_{B} \beta^{2}\right)}{C^{\prime \prime}\left(e^{*}\right)\left(1+\lambda_{B} \beta^{2}\right)^{2}}>0
$$

That is, as expected, a central banker who cares more about employment (has a larger $\lambda_{B}$ ) makes a greater effort to learn about the supply shock $\varepsilon$.

Now consider society's problem. Let $E L$ denote the government's expected loss given that the central banker has parameter $\lambda_{B}$ and accordingly exerts effort $e^{*}\left(\lambda_{B}\right)$. We get

$$
\begin{aligned}
E L & =\iint L\left(\pi_{B}^{*}\right) f(\varepsilon, s) d \varepsilon d s \\
& =\left(\lambda_{B} \beta \bar{x}\right)^{2}-\frac{\lambda_{B} \beta^{2} e^{*} \sigma^{2}}{\left(1+\lambda_{B} \beta^{2}\right)^{2}}\left[\lambda\left(2+\lambda_{B} \beta^{2}\right)-\lambda_{B}\right]+\lambda\left(\sigma^{2}+\bar{x}^{2}\right),
\end{aligned}
$$

where the expression after the second equality sign again was obtained by using equations (2.3), (2.4), (3.3), and the identity $e=\rho^{2}$.

Differentiating $E L$ with respect to $\lambda_{B}$ yields

$$
\frac{\partial E L}{\partial \lambda_{B}}=2 \beta^{2} \bar{x}^{2} \lambda_{B}-\frac{2 \beta e^{*} \sigma^{2}\left(\lambda-\lambda_{B}\right)}{\left(1+\lambda_{B} \beta^{2}\right)^{3}}-\frac{\lambda_{B} \beta^{2} \sigma^{2}}{\left(1+\lambda_{B} \beta^{2}\right)^{2}}\left[\lambda\left(2+\lambda_{B} \beta^{2}\right)-\lambda_{B}\right] \frac{\partial e^{*}}{\partial \lambda_{B}} .
$$

By inspecting equation (3.8), we can identify three different effects regarding society's incentives to appoint a central banker with certain preferences, each effect 
corresponding to one of the three terms of the right-hand side of the equation. The first term is the only one containing $\bar{x}$, and it vanishes if $\bar{x}=0$. This term captures the familiar "Rogoff effect," i.e., society's incentives to appoint a central banker who cares less about employment than itself in order to mitigate the inflation bias. The third term captures the "information acquisition effect." If the condition $\lambda\left(2+\lambda_{B} \beta^{2}\right)>\lambda_{B}$ is met, then this effect counteracts the Rogoff effect; this condition guarantees that it is in society's interest that the central banker acquires more information. ${ }^{5}$ If society appoints a central banker who cares more about employment than itself, this central banker will exert more effort looking for information and, hence, she will be more able to stabilize employment. This effect would vanish if the quality of the signal were exogenous. The second term in (3.8) represents the incentives of society to delegate the task of deciding on monetary policy to a central banker who will stabilize employment neither too little nor too much. Indeed, if we had $\bar{x} \equiv \partial e^{*} / \partial \lambda_{B} \equiv 0$, then both the first and the third term would vanish, and we would get the result $\lambda_{B}=\lambda$; that is, society would then appoint a central banker with the same preferences as society itself.

Thus, we can easily get back Rogoff's (1985) result by setting $\partial e^{*} / \partial \lambda_{B}=0$ and $e^{*}=\rho^{2}$ in (3.8). Doing this and setting the resulting expression equal to zero yield:

$$
\beta \bar{x}^{2} \lambda_{B}-\frac{\rho^{2} \sigma^{2}\left(\lambda-\lambda_{B}\right)}{\left(1+\lambda_{B} \beta^{2}\right)^{3}}=0 .
$$

As Rogoff showed, in this case the optimal $\lambda_{B}$ will be strictly smaller than society's own $\lambda$ parameter but strictly greater than zero.

To see in a stark way how the information acquisition effect works, let us temporarily eliminate the Rogoff effect by setting $\bar{x}=0$ in (3.8). Let $\lambda_{B}^{0}$ denote a solution to the problem of minimizing $E L$ with respect to $\lambda_{B}$, given $\bar{x}=0$ and subject to the constraint $\lambda_{B} \in[0, \infty)$. Moreover, for $\lambda \beta^{2}<1$, let $\widehat{\lambda}$ be defined by $\widehat{\lambda}=2 \lambda /\left(1-\lambda \beta^{2}\right)$.

Proposition 1. Suppose that $\bar{x}=0$ and $\lambda \beta^{2}<1$. Then $\lambda_{B}^{0} \in(\lambda, \widehat{\lambda})$ and $\lambda_{B}^{0}$ satisfies

$$
2\left(\lambda-\lambda_{B}^{0}\right)+\left(1+\lambda_{B}^{0} \beta^{2}\right)\left[\lambda\left(2+\lambda_{B}^{0} \beta^{2}\right)-\lambda_{B}^{0}\right] \eta\left(\lambda_{B}^{0}\right)=0,
$$

where $\eta\left(\lambda_{B}\right)=\frac{\partial e^{*}}{\partial \lambda_{B}} \frac{\lambda_{B}}{e^{*}}$.

Proof: Note that the first term in (3.8) is zero when $\bar{x}=0$; the second term in (3.8) has the same sign as $\left(\lambda_{B}-\lambda\right)$; the third term has the same sign as $\left(\lambda_{B}-\hat{\lambda}\right)$.

\footnotetext{
${ }^{5}$ Hence, if the condition is not met, an individual with taste parameter $\lambda$ is worse off when a decision maker with taste parameter $\lambda_{B}$ is better informed. For a discussion of this phenomenon, see Lagerlöf (1999).
} 
Hence, the function $E L$ is strictly decreasing in $\lambda_{B}$ for all $\lambda_{B} \in[0, \lambda]$, and it is strictly increasing in $\lambda_{B}$ for all $\lambda_{B} \in[\widehat{\lambda}, \infty)$. This, in turn, means that $E L$ must have at least one minimum with respect to $\lambda_{B}$ somewhere on the open interval $(\lambda, \widehat{\lambda})$. Moreover, at a point where $E L$ is minimized, we must have

$$
\left.\frac{\partial E L}{\partial \lambda_{B}}\right|_{\bar{x}=0, \lambda_{B}=\lambda_{B}^{0}}=0
$$

Rewriting this equality yields (3.10).

That is, when the Rogoff effect is eliminated (i.e., when $\bar{x}=0$ ), society delegates to a central banker who cares more about employment than itself. From Proposition 1 and from a continuity argument it follows that there also must be some $\bar{x}>0$ such that the optimal $\lambda_{B}$ still is greater than $\lambda$; that is, society will delegate to a banker who cares more about employment than itself also in the case where there indeed is a Rogoff effect present, provided this effect (i.e., $\bar{x}$ ) is sufficiently small. Another thing one should notice about the proposition is that it assumes that $\lambda$ and/or $\beta$ are sufficiently small. If this condition $\left(\lambda \beta^{2}<1\right)$ is not met, society's optimization problem might not have a solution; this is because then society might want to make $\lambda_{B}$ arbitrarily large.

The following example illustrates the result stated in Proposition 1 and shows that with a quadratic cost function we can get a closed form solution for $\lambda_{B}^{0}$.

Example 1: Suppose that $\bar{x}=0, \lambda \beta^{2}<1$, and that $C(e)=\frac{1}{2} e^{2}$. Using (3.5), we then get

$$
e^{*}=\min \left\{\frac{\beta^{2} \sigma^{2}\left(\lambda_{B}^{0}\right)^{2}}{1+\beta^{2} \lambda_{B}^{0}}, 1\right\} .
$$

Assuming that the less-than-unity constraint does not bind, ${ }^{6}$ we also get

$$
\eta\left(\lambda_{B}^{0}\right)=\frac{2+\beta^{2} \lambda_{B}^{0}}{1+\beta^{2} \lambda_{B}^{0}}
$$

Using (3.13) in (3.10) and then simplifying and solving for $\lambda_{B}^{0}$ in turn yield

$$
\lambda_{B}^{0}=\frac{1}{\beta^{2}}\left[\sqrt{\frac{2\left(2+\lambda \beta^{2}\right)}{1-\lambda \beta^{2}}}-2\right] .
$$

\footnotetext{
${ }^{6}$ Since it turns out that $\lambda_{B}^{0}$ is not a function of $\sigma^{2}$, it is easy to see that this constraint does not bind if $\sigma^{2}$ is sufficiently small. In particular, since we know that $\lambda_{B}^{0}<\widehat{\lambda}$, a sufficient condition for this is that $\sigma^{2} \leq\left(1+\beta^{2} \widehat{\lambda}\right) / \beta^{2} \widehat{\lambda}^{2}=\left[1-\left(\lambda \beta^{2}\right)^{2}\right] / 4 \lambda^{2} \beta^{2}$.
} 
This expression for $\lambda_{B}^{0}$ is (strictly) increasing in both $\lambda$ and $\beta,{ }^{7}$ which is in line with our intuition. One can also show that $\lim _{\beta \rightarrow 0} \lambda_{B}^{0}=3 \lambda / 2$. Hence, in this example we have $\lambda_{B}^{0} \in(3 \lambda / 2, \hat{\lambda})$; that is, here it is optimal to delegate to a banker with a $\lambda$-parameter that is at least 1.5 times society's own.

Let us now again allow for the possibility that $\bar{x}>0$. Let $\lambda_{B}^{*}$ denote a solution to the problem of minimizing $E L$ with respect to $\lambda_{B}$, again subject to the constraint $\lambda_{B} \in[0, \infty)$ but now not necessarily with $\bar{x}=0 .{ }^{8}$ To see when the information acquisition effect is stronger than the Rogoff effect, so that $\lambda_{B}^{*}>\lambda$, let us evaluate equation (3.8) at $\lambda_{B}=\lambda_{B}^{*}=\lambda$. Doing this yields

$$
\left.\frac{\partial E L}{\partial \lambda_{B}}\right|_{\lambda_{B}=\lambda_{B}^{*}=\lambda}=-2 \lambda \beta^{2} \bar{x}^{2}+\left.\frac{\beta^{2} \lambda^{2} \sigma^{2}}{1+\lambda \beta^{2}} \frac{\partial e^{*}}{\partial \lambda_{B}}\right|_{\lambda_{B}=\lambda_{B}^{*}=\lambda}
$$

If we assume that society's expected loss, $E L$, is quasi-convex in $\lambda_{B}$ (i.e., that the second-order condition is met), then we will have $\lambda_{B}^{*}>\lambda$ if (and only if) the right-hand side of equation (3.15) is greater than zero, or equivalently

$$
\left.\frac{\partial e^{*}}{\partial \lambda_{B}}\right|_{\lambda_{B}=\lambda_{B}^{*}=\lambda}>\frac{2 \bar{x}^{2}\left(1+\lambda \beta^{2}\right)}{\lambda \sigma^{2}} .
$$

By rewriting this inequality, using the expression for $\partial e^{*} / \partial \lambda_{B}$ in (3.6), we get the following proposition.

Proposition 2. Suppose that $E L$ is quasi-convex in $\lambda_{B}$. Then $\lambda_{B}^{*}>\lambda$ if and only if

$$
\bar{x}^{2}<\frac{\beta^{2}\left(\sigma^{2}\right)^{2} \lambda^{2}\left(2+\lambda \beta^{2}\right)}{2 C^{\prime \prime}\left(e^{*}\right)\left(1+\lambda \beta^{2}\right)^{3}} \equiv \varphi\left(\beta^{2}, \sigma^{2}, \lambda\right),
$$

where $e^{*}$ is evaluated at $\lambda_{B}=\lambda_{B}^{*}=\lambda$.

Hence, if the employment goal, $\bar{x}$, is small relative to the right-hand side of $(3.17), \varphi$, and if the second-order condition is met, society will delegate the task of conducting monetary policy to someone more "liberal" than itself. It is straightforward to see that the function $\varphi$ is positive if all its arguments are positive. However, as the following example shows, this function is not necessarily monotone in anyone of its arguments.

\footnotetext{
${ }^{7}$ In order to check that $\partial \lambda_{B}^{0} / \partial \beta>0$, it is helpful to first set $\beta^{2}=\gamma$ in (3.14). Then it is fairly straightforward to verify that $\partial^{2} \lambda_{B}^{0} / \partial \gamma \partial \lambda>0$ and that $\lim _{\lambda \rightarrow 0} \partial \lambda_{B}^{0} / \partial \gamma=0$; these two things together imply the claim.

${ }^{8}$ In the following it is implicitly assumed that $\lambda_{B}^{*}$ indeed exists. If $\lambda_{B}^{*}$ did not exist, this would be because society has the incentive to make $\lambda_{B}$ arbitrarily large.
} 
Example 2: Suppose that $C(e)=(1-\sqrt{1-e})^{2}$. Using (3.5), we get

$$
C^{\prime \prime}\left(e^{*}\right)=\frac{1}{2}\left[\frac{1+\beta^{2} \lambda_{B}\left(1+\sigma^{2} \lambda_{B}\right)}{1+\beta^{2} \lambda_{B}}\right]^{3} .
$$

Hence,

$$
\varphi\left(\beta^{2}, \sigma^{2}, \lambda\right)=\frac{\beta^{2}\left(\sigma^{2}\right)^{2} \lambda^{2}\left(2+\lambda \beta^{2}\right)}{\left[1+\beta^{2} \lambda\left(1+\sigma^{2} \lambda\right)\right]^{3}} .
$$

It is easy to verify that this expression for $\varphi$ equals zero if anyone of its arguments equals zero, and it goes to zero as either one of its arguments goes to infinity. Thus, in this example, $\varphi$ will obtain its highest value - and thereby make it more likely that inequality (3.17) holds - for some intermediate value of $\beta, \sigma^{2}$, respectively $\lambda$.

\section{Conclusion}

This paper has studied an extension of Rogoff (1985) where the central banker can choose how much effort to exert and, thereby, how much to learn about a supply shock. It was shown that, with this assumption, society's incentive to delegate to a banker who is more conservative than itself is mitigated. Indeed, if the credibility problem in Rogoff's original model (as measured by the size of the difference between the employment goal and the "natural" employment level) is not too severe, it is optimal for society to delegate to a more "liberal" banker. Two things drive this result. First, at least some of the cost of exerting effort (or acquiring information) is incurred by the banker personally. Second, the contract that society can write is sufficiently incomplete. As noted in the introduction, both these assumptions have been made earlier in the literature (by Walsh (1995) respectively Herrendorf and Lockwood (1997)), although not at the same time; and none of the assumptions seems to be unreasonable. The contribution of the present paper has been to show what the two assumptions in conjunction imply for the optimal choice of central bank objectives. It has also been suggested that the results of the paper may explain why many individuals in many countries object to the idea of delegating the conduct of monetary policy to an independent and conservative central banker. 


\section{References}

Barro, R.J., and D.B. Gordon, 1983, A positive theory of monetary policy in a natural rate model, Journal of Political Economy 91: 589-610.

Herrendorf, B., and B. Lockwood, 1997, Rogoff's "conservative" central banker restored, Journal of Money, Credit, and Banking 29: 476-495.

Kydland, F.E., and E.C. Prescott, 1977, Rules rather than discretion: The inconsistency of optimal plans, Journal of Political Economy 85: 473-491.

Lagerlöf, J., 1999, Are we better off if our politicians know how the economy works?, WZB Discussion Paper No. FS IV 98-7, revised version May 1999.

Muscatelli, V. A., 1999, Inflation contracts and inflation targets under uncertainty: Why we might need conservative central bankers, Economica 66: 241-254.

Persson, T., and G. Tabellini, 1997, Political economics and macroeconomic policy, CEPR Discussion Paper No. 1759, forthcoming in Handbook of Macroeconomics, eds. John Taylor and Michael Woodford.

Persson, T., and G. Tabellini, 1993, Designing institutions for monetary stability, Carnegie-Rochester Conference Series on Public Policy 39: 53-84.

Persson, T., and G. Tabellini, 1997, Political economics and macroeconomic policy, CEPR Discussion Paper No. 1759, forthcoming in Handbook of Macroeconomics, eds. John Taylor and Michael Woodford.

Rogoff, K., 1985, The optimal degree of commitment to an intermediate monetary target, Quarterly Journal of Economics 100: 1169-1190.

Walsh, C.E., 1995, Optimal contracts for central bankers, American Economic Review 85: 150-167. 


\section{Bücher des Forschungsschwerpunkts Marktprozeß und Unternehmensentwicklung}

\section{Books of the Research Area Market Processes and Corporate Development}

(nur im Buchhandel erhältlich/available through bookstores)

Horst Albach, Ulrike Görtzen, Rita Zobel (Hg.)

Information Processing as a Competitive

Advantage of Japanese Firms

1999, edition sigma

Dieter Köster

Wettbewerb in Netzproduktmärkten

1999, Deutscher Universitäts-Verlag/Gabler Verlag

Christian Wey

Marktorganisation durch Standardisierung: Ein

Beitrag zur Neuen Institutionenökonomik des

Marktes

1999, edition sigma

Horst Albach, Meinolf Dierkes, Ariane Berthoin

Antal, Kristina Vaillant (Hg.)

Organisationslernen - institutionelle und

kulturelle Dimensionen

1998, edition sigma

Lars Bergman, Chris Doyle, Jordi Gual, Lars Hultkrantz, Damien Neven, Lars-Hendrik Röller, Leonard Waverman

Europe's Network Industries: Conflicting

Priorities - Telecommunications

Monitoring European Deregulation 1

1998, Centre for Economic Policy Research

Manfred Fleischer

The Inefficiency Trap

Strategy Failure in the

German Machine Tool Industry

1997, edition sigma

Christian Göseke

Information Gathering and Dissemination

The Contribution of JETRO to

Japanese Competitiveness

1997, Deutscher Universitäts-Verlag

Andreas Schmidt

Flugzeughersteller zwischen globalem

Wettbewerb und internationaler Kooperation

Der Einfluß von Organisationsstrukturen auf

die Wettbewerbsfähigkeit von

Hochtechnologie-Unternehmen

1997, edition sigma

Horst Albach, Jim Y. Jin, Christoph Schenk (eds.)

Collusion through Information Sharing?

New Trends in Competition Policy

1996, edition sigma
Stefan O. Georg

Die Leistungsfähigkeit japanischer Banken

Eine Strukturanalyse des Bankensystems in Japan

1996, edition sigma

Stephanie Rosenkranz

Cooperation for Product Innovation

1996, edition sigma

Horst Albach, Stephanie Rosenkranz (eds.)

Intellectual Property Rights and Global

Competition - Towards a New Synthesis

1995, edition sigma.

David B. Audretsch

Innovation and Industry Evolution

1995, The MIT Press.

Julie Ann Elston

US Tax Reform and Investment: Reality and Rhetoric in the 1980s

1995, Avebury

Horst Albach

The Transformation of Firms and Markets:

A Network Approach to Economic

Transformation Processes in East Germany

Acta Universitatis Upsaliensis, Studia Oeconomiae

Negotiorum, Vol. 34

1994, Almqvist \& Wiksell International

(Stockholm).

Horst Albach

"Culture and Technical Innovation: A Cross-

Cultural Analysis and Policy

Recommendations"

Akademie der Wissenschaften zu Berlin (Hg.)

Forschungsbericht 9, S. 1-597

1994, Walter de Gruyter.

Horst Albach

Zerissene Netze. Eine Netzwerkanalyse des ostdeutschen Transformationsprozesses

1993, edition sigma.

Zoltan J. Acs/David B. Audretsch (eds)

Small Firms and Entrepreneurship: An East-

West Perspective

1993, Cambridge University Press.

Anette Boom

Nationale Regulierungen bei internationalen Pharma-Unternehmen: Eine theoretische

Analyse der Marktwirkungen

1993, Nomos Verlagsgesellschaft. 
Horst Albach

Dietmar Harhoff

Karel Cool Lars-Hendrik Röller Benoit Leleux

Horst Albach

Shiho Futagami Tomoki Waragai Thomas Westphal

Dietmar Harhoff Timm Körting

Johan Lagerlöf

Justus Haucap Christian Wey Jens Barmbold

Manfred Fleischer

Dieter Köster

Andreas Blume

Andreas Blume Uri Gneezy

Andreas Blume Douglas V. DeJong George R. Neumann Nathan E. Savin

Hans Mewis

Lars-Hendrik Röller Mihkel M. Tombak Ralph Siebert

Christine Zulehner

Catherine Matraves
Unternehmensgründungen in Deutschland

FS IV $98-1$

Potentiale und Lücken

Vertical Organization, Technology Flows and R\&D Incentives - An Exploratory Analysis

Der Einfluß des tatsächlichen und des potentiellen Wettbewerbs auf die Rentabilität von Unternehmen der pharmazeutischen Industrie

Blühende Landschaften?

Ein Beitrag zur Transformationsforschung

FS IV $98-4$

Shukko in Japanese Companies and its Economic and Managerial Effects

Lending Relationships in Germany: Empricial Results from Survey Data

FS IV $98-6$

FS IV $98-7$ How the Economy Works?

Location Costs, Product Quality, and Implicit Franchise Contracts

FS IV $98-8$

FS IV $98-9$

Patenting and Industrial Performance: The Case of the Machine Tool Industry

Was sind Netzprodukte? - Eigenschaften, Definition und Systematisierung von Netzprodukten

FS IV $98-10$

Coordination and Learning with a Partial Language

FS IV $98-11$

An Experimental Investigation of Optimal Learning FS IV 98 - 12 in Coordination Games

Learning in Sender-Receiver Games

FS IV $98-13$

The Stability of Information Cascades: How Herd Behavior Breaks Down

FS IV $98-14$

The Incentives to Form Research Joint Ventures: Theory and Evidence

FS IV $98-15$

Econometric Analysis of Cattle Auctions

FS IV $98-16$

Market Structure, R\&D and Advertising in the Pharmaceutical Industry 


\section{DISCUSSION PAPERS 1999}

Suchan Chae Paul Heidhues

Christian Wey

Horst Albach

Jeremy Lever

Damien J. Neven Lars-Hendrik Röller Zhentang Zhang

Justus Haucap Uwe Pauly Christian Wey

Jianbo Zhang Zhentang Zhang

Justus Haucap Christian Wey

Yasar Barut Dan Kovenock Charles Noussair

Jim Y. Jin

Jos Jansen

Johan Lagerlöf

Catherine Matraves

Pinelopi Koujianou Goldberg Frank Verboven

Olivier Cadot Lars-Hendrik Röller Andreas Stephan

Holger Derlien Tobias Faupel Christian Nieters
Bargaining Power of a Coalition in Parallel Bargaining: FS IV $99-1$ Advantage of Multiple Cable System Operators

Compatibility Investments in Duopoly with Demand FS IV 99 - 2 Side Spillovers under Different Degrees of Cooperation

Des paysages florissants? Une contribution FS IV 99 - 3 à la recherche sur la transformation

The Development of British Competition Law: A Complete Overhaul and Harmonization

Union Power and Product Market Competition: Evidence from the Airline Industry

FS IV $99-4$

FS IV $99-5$

The Incentives of Employers' Associations to

FS IV $99-6$ Raise Rivals' Costs in the Presence of Collective Bargaining

Asymptotic Efficiency in Stackelberg Markets with Incomplete Information

FS IV $99-7$

Standortwahl als Franchisingproblem

FS IV 99 - 8

A Comparison of Multiple-Unit All-Pay and

FS IV $99-9$ Winner-Pay Auctions Under Incomplete Information

Collusion with Private and Aggregate Information

FS IV $99-10$

Strategic Information Revelation and Revenue Sharing in an R\&D Race with Learning Labs

FS IV $99-11$

FS IV $99-12$

Incomplete Information in the Samaritan's Dilemma: The Dilemma (Almost) Vanishes

Market Integration and Market Structure in the European Soft Drinks Industry: Always Coca-Cola?

FS IV $99-13$

FS IV $99-14$ The Evolution of Price
European Car Market

A Political Economy Model of Infrastructure

FS IV $99-15$ Allocation: An Empirical Assessment

FS IV $99-16$

Industriestandort mit Vorbildfunktion?

Das ostdeutsche Chemiedreieck 
Absender/From:

Versandstelle - WZB

Reichpietschufer 50

D-10785 Berlin

\section{BESTELLSCHEIN / ORDERFORM}

Bitte schicken Sie mir aus der Liste der Institutsveröffentlichungen folgende Papiere zu:
Bitte schicken Sie bei Ihren Bestellungen von WZB-Papers unbedingt eine 1-DM-Briefmarke pro paper und einen an Sie adressierten Aufkleber mit. Danke.

For each paper you order please send a "Coupon-

Réponse International" (international money order) plus a self-addressed adhesive label. Thank You.

Please send me the following papers from your Publication List: 